\title{
BYRON AND THE POST-SECULAR: QUIA IMPOSSIBILE
}

Towards the beginning of Canto XVI of Don Juan, Byron's narrator-who a few stanzas earlier referred to himself as 'a temperate theologian' (XV, 92)—quotes from De Carne Christi, a polemical riposte to the heretical doceticism of Marcion of Sinope, by the second-century theologian Tertullian, though he mistakenly attributes the saying to Augustine:

[...] Saint Augustine has the great priority, Who bids all men believe the impossible, Because 'tis so. Who nibble, scribble, quibble, he Quiets at once with 'quia impossibile'.

And therefore, mortals, cavil not at all;

Believe:-if 'tis improbable you must, And if it is impossible, you shall:

'Tis always best to take things upon trust. I do not speak profanely, to recall

Those holier mysteries which the wise and just

Receive as gospel [...]. (XVI, 5-6)

In citing and appearing to endorse Tertullian's paradoxical credo, as is often the case in Byron's poem, it's hard to tell where the narrator's tongue is in relation to his cheek; for although his 'I do not speak profanely' appears to confirm a reputation for irreverencein suggesting that he expects his audience not to take the allusion seriously—and whilst the notoriously sceptical poet may be more inclined in the face of authority to 'nibble, scribble [or] quibble' than to 'take things upon trust', there are a couple of factors that should be weighed against these received impressions. Firstly, as G.K. Chesterton reminds us-whose own overtly religious work argues for an alliance of levity and reverence- 'funny is not the opposite of serious'; it is 'the opposite of not funny and of nothing else'. ${ }^{1}$ Likewise for Byron, seriousness and humour tend not to exist in a 'zerosum' relationship; rather, what we typically find are shimmering admixtures or 
interlacements of heterogeneous tonalities (the 'serious laughter' of which the poet speaks is but one example of these mingled tonalities). ${ }^{2}$ What's more, as Bernard Beatty has observed, Byron's jokes introduce ideas and make available vocabularies that are 'intended to affect the reader in more ways than a joke'. ${ }^{3}$ Secondly, Byron's invocation of the 'quia impossibile' is buttressed immediately afterwards by a claim of his own about the need to venture in the cause of truth beyond secular reason:

I merely mean to say what Johnson said, That in the course of some six thousand years, All nations have believed that from the dead A visitant at intervals appears;

And what is strangest upon this strange head, Is, that whatever bar the reason rears

'Gainst such belief, there's something stronger still

In its behalf, let those deny who will. (XVI, 7)

One of the interesting things about this stanza, which recalls the epigraph to Manfred ('There are more things in heaven and earth, Horatio, / Than are dreamt of in your philosophy'), is that it presents a carefully reasoned argument in favour of that which exceeds reason. In this way, by anticipating objections ('let those deny who will'), by openly acknowledging the oddity of his claim ('what is strangest upon this strange head') and in citing the support of the exemplary rationalist Johnson, the speaker attempts to persuade us of his commonsensical view of the things and to make clear that this is not a momentary or impassioned fancy but rather a settled and accepted belief, which transcends but does not extinguish reason, since the latter registers its own surpassing. And it is in asserting, in a settled and reasoned manner, that there are certain things in 'heaven and earth' that compel assent in spite of the interdictions of reason-beliefs, that is, which are paradoxically sanctioned by even as they carry us beyond reason-that Byron's narrator is advocating a position that is in certain important respects consonant with Tertullian's. 
Principally, what the two claims have in common—and what Byron, it seems, wishes to elicit from the reader-is a paradoxical openness to the possibility of the impossible. ${ }^{4}$ To be sure, there are differences between the claims. Tertullian's assertion is a claim about God that has its basis in Scripture, most obviously, as the immediate context reveals, Paul's comments in 1 Corinthians 1 about the foolishness of the Crucifixion (though we also find a logic of 'possible impossibility' in the Gospels: when Mary, for example, asks the angel Gabriel how she is to conceive since she is a virgin, the angel explains that 'with God nothing shall be impossible'; and when the disciples ask Jesus - who has just told them it is easier for a camel to pass through the eye of a needle than for a rich man to enter the kingdom of God-who can be saved, Christ responds: With men this is impossible; but with God all things are possible ${ }^{5}$ ). This tendency to associate God with the paradoxical possibility of the impossible leads the fifteenthcentury German theologian Nicholas of Cusa to suggest: 'since nothing is impossible for God, we should look for Him [...] in those things which are impossible in this world'. Byron's claim, by contrast, which emerges in the midst of a work of fiction (though he insists it's true), relates to 'visitants' from beyond the grave-a dramatization of which in the cantos that follow is the source of much comedy but also some profoundly unsettling effects, which carry us away from a purely materialist vision without unequivocally delivering us into a religious sphere. Which is a reasonable introductory summary of what I shall refer to as a 'post-secular' stance. I shall explain this further in the sections that follow, though in view of Byron's semi-facetious invocation of the 'quia impossibile' it is worth noting that a common feature of the post-secular vision is a strategy of 'ludic avowal', which John McClure describes as a way of making 'the reintroduction of the religious palatable to secular-minded readers' whilst checking 'the tendency of religious speculation to drift towards dogmatism and intolerance'. ${ }^{7}$ It's important to bear this possibility in mind, since Byron's facetious treatment of religious subjects is often taken 
to be a sign of impiety or an index of his supposed non-belief. Yet if McClure is correct, levity would appear to be a much more open and 'ambidextrous' modality, which may even turn out to be an ally of the religious.

Scripture of course is not generally associated with levity. But there is an instructive 'antiphonal' exchange of laughter in the story of Abraham, Sarah and Isaac in the book of Genesis, which helps to illustrate the antithetical valencies of levity, and also serves to drive home a lesson about the paradoxical possibility of the impossible. The first laugh proceeds from Abraham, who 'fell upon his face, and laughed, and said in his heart, Shall a child be born unto him that is an hundred years old? and shall Sarah, that is ninety years old, bear?' (17: 17). This is closely followed by the laughter of Sarah herself, who was listening outside the tent: 'Sarah laughed within herself, saying, After I am waxed old shall I have pleasure, my lord being old also?' (18: 12). Such an occurrence, for Abraham and Sarah, appears to be impossible. But God responds to their incredulous laughter by asking 'Is anything impossible for the Lord?' (18:14). ${ }^{8}$ It's hard to say precisely who has the last laugh, as it is projected to continue throughout the ages (21:6), but it is emphatically associated with the divine; for Sarah does indeed give birth, and the child is named Isaac, according to God's command, which is a transliteration of the Hebrew Yișhāq, meaning 'laugh'. Thus the book of Genesis brings together and prompts us to reflect upon two contrasting kinds of laughter: a human laughter of disbelief in the face of that which appears impossible, and a divine laughter at that disbelief, which marks the paradoxical advent of the impossible. ${ }^{9}$ Whilst Byron is well known for his scoffing, sceptical and debunking laughter, it is the poet's countervailing openness to the paradoxical possibility of the impossible with which this article will be concerned. More precisely, I wish to suggest in what follows that the contemporary post-secular paradigm — which offers a model of radical hospitality, unconstrained by the parameters of exclusionary immanence-may help us to appreciate without eliding the complexities 
of Byron's ambivalent engagement with the religious, which in the opinion of the Jesuit David Leigh has somewhat unhelpfully divided commentators on the subject into 'the party of pessimism' and 'the salvation critics'. ${ }^{10}$

\section{DEMYSTIFICATION IN REVERSE}

In order to explain what is meant by the post-secular and why it is of relevance to the Romantics, it will be helpful to say something—however summarily—about the 'secular' to which it is 'post'. One of the most comprehensive accounts of this has been provided by Charles Taylor in A Secular Age. Broadly speaking, what Taylor describes in this monumental 900 page work is the extremely complex and profound shift in the West from a life lived beneath the 'scared canopy', ${ }^{11}$ imbued with a providential aura of the holy, to a 'disenchanted' world of 'exclusive humanism' and instrumental reason. ${ }^{12}$ Two of the defining features of this historical development are, firstly, the shift from a premodern 'porous' self, which was 'always already entwined with its beyond' and 'essentially open to an outside'-be it 'blessing or curse, possession or grace'- to what Taylor describes as a 'buffered' self, which is 'insulated and isolated in its interiority'; and secondly, a process of 'immanentization' or a correlative shift from a world that is normatively conceived as open to transcendence-in that, for the majority of people, the material order is suffused with and mediates that which exceeds it- to a realm of unsundered and enclosed materialism, which Taylor refers to as the 'immanent frame'. ${ }^{14}$ (In the concluding section of this article I shall suggest that this distinction between a 'closed immanence' and an openness to transcendence has an important but largely unacknowledged corollary in criticism of Byron.)

The roots of this process of 'disenchantment' and the concomitant emergence of a 'de-transcendentalized' sphere-which is viciously satirized by Carlyle's Teufelsdröckh 
in Sartor Resartus—most prominently lie, on the one hand, in the Enlightenment venture of separateness, which, although it wasn't opposed to religion as such, but rather particular conceptions of God and certain features of pre-modern Christianity (such as mystery, supernaturalism and sacerdotal practices), nonetheless understood itself as a 'release from self-incurred tutelage' under the guidance of secular reason. ${ }^{15}$ On the other hand, however, the Enlightenment's 'empty[ing] of the haunted air ${ }^{16}$ was itself made possible by prior and even more profound changes within the religious sphere, which led to the loss of a 'sacramental' worldview or what Peter Berger refers to as a demise of the supernatural. ${ }^{17}$ This was drastically accelerated by the Protestant Reformation, which in general reinforced the separation of nature and the supernatural, rejecting their integration in the sacramental ontology of the patristic Platonic-Christian vision. Yet the foundations of this sacramental worldview had already been undermined by the emergence in the late medieval period of 'univocity' and 'nominalism', which according to Hans Boersma, were 'the two blades of a pair of scissors' that severed 'the participatory link between earthly sacrament [...] and heavenly reality'. ${ }^{18}$ So, what Taylor_after Max Weber_-refers to as 'disenchantment' can be seen as part of a larger historical tendency characterized by the 'descramentalizing' of Western culture, a searingly sarcastic assessment of which is provided by Novalis in the fragment Christendom or Europe.

Now whilst in general I want to hold onto the disenchantment thesis as a helpful, if very approximate, way of describing certain historical changes, there are a number of complications that need to be acknowledged. In the first place, it is important to note that there are several competing models of secularization, only some of which reflect the unilinear process of demystification and religious decline that is posited in Weber's narrative. (The 'God is Dead' model put forward by Steve Bruce is a well-known example of this 'one-way' disenchantment. ${ }^{19}$ ) Such unilinear conceptions of 
secularization have, for instance, been contested by José Casanova, whose 'differentiation' thesis argues that secularization doesn't necessarily entail religious decline and may instead involve an emancipation of secular spaces and cultural authority from the control of religious institutions ${ }^{20}$ by Peter Berger, who-even in the $1960 \mathrm{~s}$ observed that 'secularization consciousness is not the absolute it presents itself as'; ${ }^{21}$ and more recently by Patrick Sherry, who-with particular reference to a Catholic perspective- has argued that 'enchantment' never entirely went away. ${ }^{22}$

Even so, that something resembling the general tendency towards 'disenchantment' described by Weber took place in the West during the period of modernity seems hard to dispute. What is also hard to dispute, however, is the unforeseen revival of the religious at the end of the twentieth and beginning of the twenty-first century. One of the more surprising features of this peripeteia-which, alongside the resurgence of fundamentalism, encompasses a bewildering array of new religions, sects and alternative spiritualities-is the way in which postmodern religion isn't simply reflected in, but also appears in reverse to be fostered by, the prevalence of 'enchanted' visions in contemporary culture, which as Christopher Partridge has argued, vitally shape the 'plausibility structures of Westerners' ${ }^{23}$ (It is part of the argument of this article that we are witnessing — and should welcome-the parallel emergence of a critical approach in Romantic studies that renounces the immanentizing assumptions of exclusive secularism and is instead open to, even as it is prepared to question, the possibility of radical transcendence..$^{24}$ )

A similar point has been made by John Caputo in relation to advances in electronic forms of communication and the parallel distention of virtual reality, which offers us analogues of such things as disembodied interconnectivity or communion-inabsence, which inevitably affect our sense of what is possible, believable and real. ${ }^{25}$ Indeed, one might say that the advent of virtual reality has led to something of a revival 
of allegorical practices, since if the industrial revolution disfigured what Wordsworth referred to as 'the speaking face of earth and heaven' (The Prelude, V, 11-12), the digital revolution has opened up a plethora of new 'speaking' spaces and made possible previously unthinkable experiences of transcendence, communion or being 'outside' oneself. This is not to say, I should immediately add, that such things are intrinsically religious; the point is, rather, that they may help us to imagine, articulate or try on theological conceptions of the world, which may of course be purely 'aesthetic' experiences that elicit no metaphysical reflections; yet they may equally prompt us to wonder whether these digitized infinities and 'ecstatic' experiences of quasitranscendence might have analogues outside cyberspace. In other words, I am suggesting, virtual reality has serendipitously opened up a new, if somewhat paradoxical, realm of 'natural theology'. Thus, in all sorts of unexpected areas, we can see a perforation of the 'closed immanence' that according to Taylor characterized the 'secular age'. ${ }^{26}$ This partial recovery of a pre-modern 'porosity' manifestly differs-in its whence, its whither, its mood and its tonality — from the model of transcendence it ostensibly inherits. Very briefly, what I mean by this is that the 'post-secular' sense of transcendence seems, paradoxically, to be founded on scepticism as much as if not more than it is on faith; its envisioning of the beyond tends to be characterized either by an anonymous 'excess' or an 'ontological abundance'; ${ }^{27}$ its positings of transcendence are more often than not conducted in a 'weakened' subjunctive mood or expressed as an interrogative longing; and its affirmations of faith typically exhibit a tonal reserve, in adopting a ludic or ironic cast. In the words of the political theorist William Connolly, this sundering of the 'closed immanence' of exclusive secularism has led to the opening up of 'fugitive spaces of enchantment lodged between theistic faith and secular abstinence ${ }^{28}$ - spaces of "creative suspension" ${ }^{29}$ that are fecund with the possibilities of both perspectives, and as such are hospitable to new ways of thinking. These 'porous' or 
'enchanted' spaces—which renounce a secular construal of reality without adopting an exclusively religious stance—are the hallmark of a post-secular outlook.

It is, I think, possible to distinguish broadly between two forms of such 'enchanted' openness, one of which is more conceptual, the other more affective. The first of these has been brought into view by the contemporary French philosopher and founder of the 'speculative realism' movement, Quentin Meillassoux, whose testimony is especially persuasive as it is a predicament he in no way wishes to promote. Speaking of the postmodern 'de-absolutization of thought', he writes:

Far from abolishing the value of the absolute, the process that continues to be referred to today as 'the end of absolutes' grants the latter an unprecedented licence $[\ldots]$. The end of metaphysics, understood as the 'de-absolutization of thought', is thereby seen to consist in the rational legitimation of any and every variety of religious [...] belief in the absolute, so long the latter invokes no authority beside itself. To put it in other words: by forbidding reason any claim to the absolute, the end of metaphysics has taken the form of an exacerbated return of the religious. $[\ldots]$

Once the absolute has become unthinkable, even atheism, which also targets God's inexistence in the manner of an absolute, is reduced to a mere belief, and hence to a religion, albeit of the nihilist kind. Faith is pitched against faith, since what determines our fundamental choices cannot be rationally proved. In other words, the de-absolutization of thought boils down to the mobilization of a fideist argument $[\ldots]^{30}$

Whilst I agree with this as a broad description of a dominant tendency in contemporary culture, it is worth noting that Meillassoux seems to view this fideistic openness solely as something negative (since, as he correctly observes, it can be used to sanction the worst forms of violence) and is uninterested in the possibility—which Byron, by contrast, was prepared to countenance - that beliefs which carry us beyond the 'bar' of reason may nonetheless orient us towards 'what is', and that there may be truths at which we cannot arrive purely by means of syllogistic reasoning.

A more positive construal of this post-secular openness to that which draws us beyond the 'bar' of reason has been somewhat flamboyantly elaborated across a series of 
works by John Caputo. What makes his reflections of particular interest in the present context, though, is their revival of interest in the paradoxical possibility of the impossible. ${ }^{31}$ (Caputo's theological ruminations on the impossible are based on the writings of Derrida—on justice, the messianic and deconstruction etc.-in which the possibility of the impossible is entertained as a corollary of the uncircumscribable openness of what is 'to come', which in guarding against closure and making room for the other sponsors a posture of unconditional hospitality, which Derrida relates to the cities of refuge in the Old Testament. ${ }^{32}$ ) In essence, Caputo views postmodernism as a counter-reaction to the rationalistic chastities of the Enlightenment project-which sought, in Kant's 'court' of pure reason, to proscribe the parameters of the knowable and the possible_-and the demystifying suspicions of Marx, Freud and Nietzsche, who more radically sought to wipe away the horizon of transcendence. In its scepticism towards such 'grand narratives'-which purport to speak with finality and context-less objectivity about the nature of the knowable, the possible and the real-postmodernism is construed by Caputo as a turning of the tide that has opened the way for more adventurous and subjunctivized exercises of rationality, and in doing so has encouraged an openness towards the possibility of the impossible. Yet, in contrast to Meillassoux, Caputo views this 'subjunctivization' of thought and the fideistic opening it encourages as a theological opportunity.

The second form of post-secular openness that I want to consider is less concerned with meaning or representation and more concerned with the realm of affect or what William Connolly refers to as 'thought-imbued intensities' subsisting below the threshold of conceptual refinement. ${ }^{33}$ Such affects, according to Connolly, open up alternative spaces of possibility that are between, anterior to or 'other than' the categories of theistic faith and secular reason, which may help to foster an ethos of 'deep pluralism' 
and a post-secular micropolitics of forbearance and generosity. Political strategies that take cognizance of such spaces are important, he writes, because:

they work on thought-imbued intensities behind conscious thoughts not readily or fully subject to conscious purview; they are important to thinking and theory because such work on oneself can sometimes untie knots in one's thinking; they are important to politics because such work can pave the way for new movement in the politics of becoming; and they are pertinent to the ethos of a pluralist culture because such work can help to install generosity and forbearance into ethical sensibilities in a world of multidimensional plurality. ${ }^{34}$

The point of importance to take from this is that affects are (not uncontroversially) supposed to liberate a space that is distended with potentiality and a pluralized openness within the smudged becoming of subjectivity, prior to the refinements of conscious perception. And whilst they are only fugitive moments on the way to awareness, these fecund interstices in conscious experience permit a different, less conceptualized encounter with things, which is radically hospitable to a diversity of possibilities.

Let us take stock of what we have covered so far. In seeking to explain what is meant by the post-secular, I have adopted two divergent approaches-one of which is more historical, the other more philosophical or conceptual—and in doing so I have attempted to accomplish two general things. On the one hand, by situating the advent of a post-secular outlook within a larger historical narrative that charts what many assumed to be the unilinear disenchantment of modernity, I have suggested that the emergence of a post-secular perspective may be seen as a form of what Mircea Eliade has referred to as 'demystification in reverse' ${ }^{35}$ or a diffident, subjunctivized form of re-enchantment. On the other hand, in the foregoing excursus on post-secular philosophy, I have attempted to highlight what I take to be the most salient feature of a post-secular stance-namely, a radical ontological hospitality, two forms of which I have illustrated here. The first, more discursive form of such hospitality, which is born of the 'porous' scepticism of postmodernity, has led to a dilation of the parameters of the possible, such that the 
impossible has paradoxically been reinstated within the realms of possibility; the second, more affective form of hospitality, associated with the domain of 'unowned' impingements or intensities anterior to conceptual refinement, has been identified as an alternative space of 'enchantment', lodged between theistic and secular commitments, which offers us ways of nurturing 'new possibilities of thinking and being'. In the next section, I want to consider why this is of relevance to the Romantics and Byron in particular.

\section{II}

\section{Prophets of THE Post-SECUlar}

In parallel with the approach of the preceding section, there are two ways considering the relevance of a post-secular perspective to the Romantics. On the one hand, it is possible to trace an historical connection, by locating Romanticism within a larger counterEnlightenment tradition that stretches back to the German philosopher Johann Georg Hamann, and which is antagonistically sustained during the period of modernity by a variety of thinkers—-such as Nietzsche, Kierkegaard and Heidegger—but which reaches its apogee in postmodernity. (Versions of this thesis have been espoused by Jonathan Israel in Radical Enlightenment and Graham Garrard in Counter-Enlightenments from the Eighteenth Century to the Present. In line with such philosophical thinkers, the literary critic John McClure has claimed that post-secularism 'has been a feature of literary thinking since the romantics' ${ }^{36}$ ) On the other hand, in more conceptual terms, we might point towards convergences between prominent Romantic preferences and salient features of a post-secular stance. And in highlighting the ontological openness of the post-secular outlook, along with its privileging of the realm of affect, we have already started to do the latter. In view of the limitations of space I shall try, in a necessarily abbreviated fashion, to illustrate something of these convergences with reference to Byron. To do so, 
I shall focus on two moments of sustained and distended receptivity to the divine, one in Don Juan and the other in Childe Harold; the first of which evinces a more reflective openness, whilst the second dramatizes a more affectively-toned response to the divine. In both cases, though, what we can see is a hospitality to that which exceeds secular rationality—or what, from its perspective, may be deemed 'the impossible'-which obviously doesn't go unquestioned in his poetry and is typically accompanied by a countervailing attention to the materiality of our predicament. However, the poet's openness to even such contested intimations of transcendence is sufficient to sunder the 'closed immanence' of an exclusively secular vision. The section of Don Juan on which I wish to focus is the description of Norman Abbey in Canto XIII. Here is part of the first 'movement'. The 'grand arch' of 'the Gothic pile':

\section{[...] frown'd superbly o'er the soil,}

And kindled feelings in the roughest heart,

Which mourn'd the power of time's or tempest's march,

In gazing on that venerable arch.

\section{$[\ldots]$}

But in a higher niche, alone, but crowned, The Virgin Mother of the God-born Child,

With her Son in her blessed arms, look'd round, Spared by some chance when all beside was spoil'd;

She made the earth below seem holy ground.

This may be superstition, weak or wild,

But even the faintest relics of a shrine

Of any worship wake some thoughts divine. (59-61)

At the centre of these stanzas is a fugitive and faltering sense of enchantment or mysterious 'excess' that at once points towards a particular historical situation and anticipates the subsequent events of the poem. This sense of 'enchantment', which simultaneously eludes and allures the narrator, is registered in a number of ways, many of which may seem innocuous in themselves and little more than the curvature of poetic fancy. Taken together, though, these lightly entertained suggestions of excessive or 
sojourning presences dilate the parameters of an ostensibly secular construction of reality. Intimations of this kind of excess—of something that exceeds the material—are apparent, for example, in lines 469-71; for whilst the faintly anthropomorphic 'frowned', at least when considered in isolation, appears to carry little ontological significance, it does, subtly, in a conventionalized manner, introduce a sense of 'excessive' life, which both reinforces and is reinforced by its ability to 'kindle feelings' in the heart of the beholder. To be sure, there is nothing supernatural about this sort of affectivity; yet it does, lightly, open up a sense of adventitious reciprocity-in spite of an ontological asymmetry—which contributes to a more pervasive impression that the place is open to something beyond it. This tentatively entertained sense of excessive presence is apparent in the next stanza too, where the narrator describes the 'twelve saints [...] sanctified in stone', whose location elevates the beholder's gaze (from the arch to a niche 'nigh to its pinnacle'). The sculpted saints are of course no longer there; but what we might refer to as their affectivity in absentia-that is, their persistence in the narrator's historical memory in spite of their absence-corresponds to another kind of 'liturgical' paradox that the narrator's description brings into view. Specifically, the faint sense of unsettled insentience that is evoked by the poet's description of the saints-who once 'stood' within a niche-corresponds to what is, from the perspective of a believer, a genuine ontological indeterminacy; for although such statues are manifestly inanimate, they are supposed to call to mind and thus in some sense 'make present' a real communion with the figures they depict, which transgresses the boundary between the worldly and the other-worldly. In their affects, therefore, the statues may be said to exceed their inanimacy. Indeed, they legitimately induce a sort of counter-rational comportment in the worshipper, who is encouraged to address deceased and absent figures as though they were alive and present. 
These intimations of 'excessive' presence are further intensified in the following stanza, which elevates the gaze of the beholder still higher and focuses on the 'Virgin Mother of the God-born child', to whom the Priory of Newstead was dedicated. Once again — in omitting to mention he is speaking about a statue and in using a verb-form implying activity — whilst preserving a tone of factual observation, the poet's description discreetly fosters the impression of a living human figure. And as in stanza 59, this sense of mediated or 'excessive' presence is reinforced by an accompanying impression of the statue's affectivity or what Ronald Finucane in another context calls 'holy radioactivity ${ }^{37}$ : 'She made the earth below seem holy ground'. (There is a lovely ambiguity in 'the earth below', which in view of the Virgin's 'extra-terrestrial' perspective and protective role permits a widening from the ground immediately beneath the statue to include the whole earth.)

Naturally, after the expression of such reverence (which recalls the Ave Maria stanzas of Canto III), the poet is assailed by a sense of embarrassment and the counterpromptings of sceptical reason ('This may be superstition weak or wild'). Yet he does not revoke his intimations of a sacralizing presence; neither does he disavow his sense of the Abbey as an 'enchanted' place; and nor does he retract the suggestion that its icon of the Virgin Mother and child may serve a 'sacramental' purpose that subverts the boundary between the terrestrial realm and the 'worlds beyond [its] perplexing waste' (DJ, XVI, 48). Indeed, to the contrary, in the face of his own reflexive scepticism, he re-affirms his view about the adventitious affectivity of hallowed places: 'even the faintest relic of a shrine—/ Of any worship—wakes some thoughts divine'. But this is not all.

The poet's description of Norman Abbey has a second symmetrical movement, which recapitulates the stages of the foregoing sequence, but modulates into a different key, with a dramatic slowing of the discourse time and a tilting away from summary 'telling' towards a 'showing' staged in front of the reader. 
A mighty window, hollow in the centre,

Shorn of its glass of thousand colourings,

Through which the deepen'd glories once could enter,

Streaming from off the sun like seraph's wings,

Now yawns all desolate: now loud, now fainter,

The gale sweeps through its fretwork, and oft sings

The owl his anthem, where the silenced quire

Lie with their hallelujahs quench'd like fire.

But in the noontide of the moon, and when

The wind is wingéd from one point of heaven,

There moans a strange unearthly sound, which then

Is musical — a dying accent driven

Through the huge arch, which soars and sinks again. (62-3)

As in the earlier stanzas where the arch 'frowned' and the saints once 'stood', here the mighty window 'yawns' and 'the silenced choir / Lie with their halleluiahs quenched like fire'. Once again, we have a strangely spectral sense of persistence, for although the choir is emphatically 'silenced', the choice of 'Lie'-like the earlier 'stood'-entails an eerie ontological indeterminacy in its unsettling of the distinction between presence and absence. And once again this tentatively ventured sense of excessive presence gives way to a bolder suggestion of other-worldly involvement, introduced by the charged initial 'But'. In this case, the intimation of a foreign iridescence-the 'strange unearthly' yet 'musical' sound - is rendered even more uncanny by the existential 'there' construction, which in giving us a verb ahead of its subject eerily dissociates the sound from its moaning. Though as with the icon of the Blessed Virgin, the arch-which is physically open to the wind-is presented as a sort of 'sacramental' aperture, which testifies to the openness of the diurnal realm to that which is beyond it. And finally, as in the foregoing sequence, the poet seems somewhat embarrassed by his own receptivity to other-worldly intimations, at which he smilingly invites us to smile, but not before re-affirming their basis in fact: 'The cause I know not, nor can solve, but such / The fact; I've heard itonce perhaps too much.' 
Earlier, I suggested that these fugitive intimations of enchantment point 'outwards' to a particular historical situation but also point 'inwards' in forecasting the poem's climactic events. I shall address the latter first, as it can be indicated more summarily.

There is an important but subtle analogy between the narrator's initial description of the Abbey-which begins in an urbane and jaunty manner ('To Norman Abbey whirled the noble pair') but unexpectedly modulates into a minor key and something more akin to a graveyard meditation — and the appearance of the ghost of the Black Friar that follows. More precisely, the narrator is haunted by the in-breaking of an otherworldly presence-which is at once disturbing and a source of humour-in a way that anticipates and proleptically corroborates the haunting of the characters by the Abbey's principal ghost (which is the most conspicuous example of the poem's hospitality to 'the impossible'). There is also, I think, a suggestive connection with the events that follow in the description of the Abbey's 'unearthly' music as 'sad, but serene' (XIII, 64), which parallels the subsequent description of Aurora as 'radiant and grave' (XV, 45). What's more, this linguistic parallel points us towards another connection, as there is a sense in which Aurora is the mirror-image of the Abbey's other spectral presence-namely, the ghost of the Black Friar-both of whom quite precisely have their being 'between two worlds' (DJ, XV, 99), although their ontological 'ec-centricity' carries them in opposite directions. What I mean by this is that if the 'worlds beyond' have more of Aurora's existence, on account of her 'self-transcending' spirituality (XVI, 48), it might be said conversely of the ghost that due to its 'excessive' materiality, the terrestrial world has more of its existence. In short, what I think these correspondences bring to light is a tentative but coherent pattern of criss-crossings between the terrestrial and the other-worldly. Let us turn now to the historical dimension. 
Byron's elegiac description of the ruined and desecrated Abbey, which—as he reminds us-once was 'Rome's', clearly foregrounds the 'godly vandalism' of the Reformation $^{38}$ (though it also refers to the damages incurred in the Civil War). Perhaps the most pointed allusion to the former is to be found in stanza 62, in which the 'mighty window' is said to be 'Shorn of its glass of thousand colourings'. 'Shorn' is an extremely odd verb to use; however, its oddity is precisely evocative, as it expresses the very deliberate-indeed, fastidious_-violence of the iconoclasts; and whilst on the one hand it registers a sense of something immoderate in need of cutting back, on the other hand in the unnaturalness of its use in this context it evokes something of the horror that the iconoclasts' systematic destruction occasioned. But there is another, less obvious reminder that the worldly events of the English Cantos take place in the shadow of the Long Reformation—and that, I suggest, is the narrator's receptivity to the Abbey's residual aura of 'enchantment'.

There are several somewhat surprising reasons why this aura of enchantment survived, albeit in an attenuated way, the Reformers' 'assault on the immanence of the holy' and their programmatic attempt to 'evacuate the divine from the material universe'. ${ }^{39}$ As Alexandra Walsham has argued, in her excellent study of the impression the Reformation left on the natural environment in Britain and Ireland, the late medieval 'economy of the sacred', with its sacramental worldview and its 'territories of grace', was not as entirely eradicated by the Reformation as many historians have hitherto thought. ${ }^{40}$ This is firstly because, in certain cases, the iconoclasts' desecration of hallowed places had the paradoxical side-effect of simultaneously re-sanctifying them and 'reproducing the awe they [were] designed to dispel'. ${ }^{41}$ As Walsham explains, both Protestants and Catholics were unwittingly affected by this paradoxical process of re-sanctification:

If defaced monasteries, shrines, chapels, wells and other topographical landmarks had the potential to become places of near veneration by the hotter sort of 
Protestants, they also served to stir up intense feelings of regret and embarrassment in those who saw them as testimonies to puritan excess and sectarian sacrilege. In turn these emotions fostered an impulse to reconsecrate spaces polluted by profane use. ${ }^{42}$

Secondly, a sense of enchantment survived because it was not uncommon for the desecration of hallowed sites to engender an unintended displacement of devotion onto 'revered spots in the natural landscape'. ${ }^{43}$ Thus, to summarize a complex argument, the Protestant programme of desacralization involved an unforeseen counter-tendency to evoke, even as it sought to extinguish, an aura of enchantment.

What is brought into view by the recent historical studies of Alexandra Walsham, Robert Scribner and others is a much more complex and much less linear narrative of 'disenchantment' than the one popularized by Max Weber; and it is to this more complex and ambivalent picture of the post-Reformation 'twilight zone ${ }^{44}$ that I propose Byron's stanzas on Norman Abbey point. In particular, whilst the poet's sceptical and ironic gestures ('This may be superstition weak or wild'; 'I've heard it-once perhaps too much') are indications of an Enlightenment mentality, his fugitive and faltering intimations of transcendence elicited by the desecrated Abbey point towards a persistence of enchantment-albeit in weakened, nostalgic or displaced ways-even amongst Protestants (or what Michael O'Neill has wittily referred to as 'Cathostants' and 'Protolics'). Something of the way in which the Reformers' programme of desacralization paradoxically engendered even as it sought to eradicate a sense of holiness is, for example, apparent in the poet's response to ruined or now absent features of the Abbey (the saints, the window, the choir etc.), whose destruction elicits a sense of enchantment in an elegiac key. Similarly, we can see something of the unintended tendency for devotion to be displaced onto the natural landscape, in response to the desecration of architectural structures, in the migrations of holiness between the Abbey and the natural 
environment described by the poet in stanzas $62-3$, in which the choir's now silenced song appears to be taken up by nature.

What I have sought to bring out in this brief reading, drawing on revised historical accounts of post-Reformation desacralization, is firstly that we can see something akin to what Scribner describes as a 'twilight zone' in Byron's envisioning of Norman Abbey, which interweaves scepticism and glimmers of levity with an elegiacally inflected sense of enchantment; and secondly that this manifestly 'fragilized' sense of enchantment—which the poet cannot sustain or unequivocally endorse-nonetheless involves an openness to the possibility of transcendence. It is this ambivalent but unforeclosed posture towards the religious that signals the opening up of a post-secular perspective avant la lettre, which has come to fruition in the postmodern period. Let us turn now to our second example.

According to William Connolly, the generative spaces of pre-conceptual becoming associated with the realm of affect may also constitute an opening in an otherwise seamlessly secular vision. Of course, there is a long and rich tradition-with its epicenter in the monastic milieu of the medieval period-in which affectivity is privileged as a religious modality (as seen, for example, in the writings of Denys the Areopagite, William of St-Thierry, Bonaventure, Bernard of Clairvaux and, more recently, Schleiermacher). Nevertheless, Connolly's association of affect with the postsecular is a timely reminder of this traditional connection-especially given the curious neglect of religious concerns in the recent 'turn to affect'. This neglect is all the more remarkable in Romantic studies, in view of the intimate interlacement of religion and feeling in so many of its authors. In what sense, then, does affect constitute a religious opening or space of enchantment in Byron's poetry? 
An obvious place to look for answers to this question is Canto III of Childe Harold (in which there is a significant increase in the use of the words 'feel' and 'feeling' relative to the preceding cantos). Here is one of the most fascinating examples:

Then stirs the feeling infinite, so felt In solitude, where we are LEAST alone; A truth, which through our being then doth melt, And purifies from self: it is a tone, The soul and source of music, which makes known Eternal harmony [...]. (94)

Byron is of course frequently criticized for his use of opaque and contorted constructions, which appear in places to mar his sense. Yet it seems to me that part of the accomplishment of this particular stanza comes from its very lack of clarity and the puzzling questions it elicits from us. This lack of clarity most prominently proceeds from the ambiguity of the key phrase 'the feeling infinite', which could either be a head noun followed by a postpositive modifier or a participial adjective followed by a head noun; but it is also encouraged by the curious absence of specified subjectivity in the first line-which employs another of the poet's eerie 'existential' constructions, which seem to serve as signals of the other-worldly ${ }^{45}$ and by the subsequent referential shuffling, across different modalities, in which 'the feeling infinite' (whatever that means) is appositionally identified first with a 'truth', which seems to imply some sort of conceptual component, and then with an a-sematic 'tone', which is glossed as the 'soul and source of music'. The kinds of questions this lack of clarity prompts are: Is it a feeling extended to infinity or an infinity endowed with feeling? Is it something that takes place within the subject or does it exist as an exterior phenomenon? Whilst the former, more 'sensual' and less religious alternatives might seem more plausible, the latter possibilities - which in positing a sentient infinity (or an infinity capable of actively 'feeling' in the sense of reaching out to or seeking to touch us) are clearly closer to a 
religious affirmation - are underwritten by the preceding stanza, which adumbrates an explicitly religious vision in which all things participate in the being of their Creator, who is envisaged as a sort of sentient infinity.

In the view of some critics, such as Philip Martin, this kind of ambiguity is a fault and a sign of the 'rather confused relationship between the poet and nature that Childe Harold III proposes'. ${ }^{46}$ Yet this seems to me to miss the point; for what we have here, I suggest, isn't confused poetry, it is an accurate description of a confused experience. For the German philosopher and theologian Schleiermacher, who was Byron's contemporary — and whose philosophical writings are unencumbered by the demands of verse-it is the nature of this 'feeling infinite' to precede and thus in a sense 'confuse' the conceptual distinctions between 'subject' and 'object', 'interior' and 'exterior'. In Schleiermacher's words, it is a 'mysterious moment' in which 'sense and its objects have, as it were, flowed into one another and become one'. ${ }^{47}$ This doesn't of course mean that it is in fact so. But it does suggest that Byron, rather than getting a rationally clear experience confused, may have been very precisely evoking an experience that was constituted by such a confusion. The second thing to notice about Byron's ambiguous presentation of 'the feeling infinite' is that it is a post-secular ambiguity, in that it is open to and keeps simultaneously in play both secular and religious interpretations of the experience.

Clearly, these reflections on Byron's conception of 'infinite feeling' barely scratch the surface of this under-examined and fascinating subject. Though they should suffice to illustrate the general contention of this section: namely, that affect, for Byron, may also perforate the ostensibly 'closed immanence' of the secular order. What's more, it may do so in a number of ways: for example, as we have seen, it can 'make known' the eternal beyond; but it can also lure the subject ecstatically 'outside' itself, in a way that discloses its 'immortal lot' (CHP, III, 74); and it can in addition 'dilate / Our spirits' in a 
manner that renders us open to that which exceeds us (CHP, IV, 158). Of course, the opening it creates is imperfect; but, as Jean-Yves Lacoste observes, 'Affection is partial; and this is not by deficit: its powerlessness to feel everything actually honours the superabundance of what appears to it'. ${ }^{48}$

So what should we take away from all this? At the outset of this article, it was suggested that adopting a post-secular perspective may help us to appreciate without eliding the complexities of Byron's ambivalent engagement with the religious. This is because the radical hospitality of the post-secular framework-which doesn't affirm any belief a priori and doesn't refuse any belief a priori, ${ }^{49}$ but instead invites us to 'dwell in possibility ${ }^{50}$ helps to resist any partisan foreclosure of the alternatives on the basis of a species of historical condescension. This posture of unconditional openness, which is founded on a postmodern epistemological humility, might appear to be something to which all critical approaches aspire. But it is by no means so. Indeed, three of the most influential strands of Romantic criticism over the last few decades have been predicated upon dogmatic refusals and prior ideological commitments, which rule out certain possibilities in advance. Marjorie Levinson's new historicist project, for example, is founded on an explicit and rather illiberal refusal of transcendence, ${ }^{51}$ the significance of which for her critical practice can hardly be overstated (for it is by assuming in advance the invalidity of the Romantics' transcendent aspirations that she can discredit the manifest themes of their poetry and read them as a displacement of socio-political realities). Similarly, the work of Paul de Man, which for all its avowals about the endless openness of the act of reading, clearly evinces a dogmatic commitment to certain nihilistic conceptions of the real—to do with 'the nothingness of human matters ${ }^{52}$ and the abyss between the subject and language — which lead him to shut down alternative possibilities as 'mystifications' by 
sheer assertion. Likewise, finally, Jerome McGann's work on on 'Romantic ideology'which he describes as a project in radical unbelief ${ }^{53}$ - assumes on the basis of prior commitments about the nature of reality that Romantic aspirations to transcendence are an escapist fantasy or a form of 'false consciousness', and so explicitly seeks to close off identification with Romanticism's 'self-representations'. ${ }^{54}$ This sort of secular fundamentalism—which takes for granted a framework of 'closed immanence' and refuses a priori the legitimacy of alternative perspectives—has been 'normalized' by years of institutional acceptance and so appears, to many, as a form of neutrality. And yet it is as dogmatically prejudicial as its religious counterparts and has, I suggest, resulted in a serious impoverishment of Romantic art. These kinds of prejudicial foreclosures are especially detrimental to a poet like Byron, who, as I have sought to show, doubts and smirks at but is also prepared to countenance the possible validity of Romantic intimations of transcendence. This possibility is, however, closed off in advance by readings of the poet that often unreflectively impose a framework of exclusionary immanence upon his works. (And there is a long tradition of critics in Byron studiesincluding Brian Wilkie, Robert Gleckner, Jerome McGann, Charles LaChance and, most recently, Clara Tuite-who have sought to 'immanentize' the world of Byron's poetry. ${ }^{55}$ ) Of course, Byron is incorrigibly sceptical and congenitally facetious about such intimations, which are interwoven amongst conflicting concerns and frailly preserved as nothing more than a possibility-perhaps even the paradoxical possibility of the impossible. And yet, as Nietzsche-that prophet of another epoch-reminds us, 'even the thought of a possibility can shatter and transform us. ${ }^{56}$

\footnotetext{
1 'On Mr. McCabe and a Divine Frivolity', Heretics (London: John Lane, 1905), 118.

${ }^{2}$ DJ, XIII, 86.

3 Byron's 'Don Juan' (London: Croom Helm, 1985), 28, n.22.
} 
${ }^{4}$ Slavoj Žižek has sought to 'rehabilitate' Tertullian's credo in Living in the End Times (London: Verso, 2011), 106 ff., in which he says of the Resurrection: 'while not logically impossible, it nonetheless clearly breaks the basic laws of what we perceive as our (material) reality'. It is this construal of 'the impossible' that I shall employ in this article.

${ }^{5}$ Luke 1:37; Matthew 19:26. Unless otherwise stated, quotations from the Bible are taken from the King James Version.

${ }^{6}$ Cited in Jasper Hopkins, A Concise Introduction to the Philosophy of Nicholas of Cusa (Minneapolis: University of Minnesota Press, 1978), 135.

${ }^{7}$ Partial Faiths: Postsecular Fiction in the Age of Pynchon and Morrison (Athens, GA: University of Georgia Press, 2007), 16.

${ }^{8}$ Holman Christian Standard Version.

${ }^{9}$ For a consideration of various possible readings of this passage, see Catherine Conybeare, The Laughter of Sarab: Biblical Exegesis, Feminist Theory, and the Concept of Delight (New York: Palgrave, 2013).

10 'Infelix Culpa: Poetry and the Skeptic's Faith in Don Juan', Keats-Shelley Journal, 28 (1979), 120.

${ }^{11}$ Peter Berger, The Sacred Canopy: Elements of a Sociological Theory of Religion (Garden City: Doubleday, 1967).

12 A Secular Age (Cambridge, MA: Belknap Press, 2007), 19.

${ }^{13}$ James K.A. Smith, How (Not) to Be Secular: Reading Charles Taylor (Grand Rapids: Eerdmans, 2014), 29-30.

${ }_{14} A$ Secular Age, chapter 15. For a useful critique of Taylor's either/or categories, see William Connolly, $A$ World of Becoming (Durham, NC: Duke University Press, 2010), 38.

${ }^{15}$ Kant, Foundations of the Metaphysics of Morals, trans. L.W. Beck ([1784] Indianapolis: Bobbs-Merrill, 1959), 85.

${ }^{16}$ Keats, Lamia, II, 236.

17 A Rumor of Angels: Modern Society and the Rediscovery of the Supernatural (New York: Doubleday, 1969).

${ }^{18}$ Heavenly Participation: The Weaving of a Sacramental Tapestry (Grand Rapids: Eerdmans, 2011), 69.

${ }^{19}$ God Is Dead: Secularization in the West (Oxford: Blackwell, 2002).

${ }^{20}$ Public Religions in the Modern World (Chicago: University of Chicago Press, 1994).

21 A Rumor of Angels, 95.

22 'Disenchantment, Re-Enchantment, and Enchantment', Modern Theology, 25:3 (2009).

${ }^{23}$ The Re-Enchantment of the West, vol. 1: Alternative Spiritualities, Sacralization, Popular Culture, and Occulture (New York: Continuum, 2004), 187.

${ }^{24}$ For a good summary discussion of this, see Michael Tomko's chapter on 'Religion', A Handbook of Romanticism Studies, ed. Joel Faflak and Julia Wright (Oxford: Blackwell, 2012).

${ }^{25}$ On Religion (London: Routledge, 2001).

${ }^{26}$ It should be noted that Taylor doesn't employ — and would doubtless resist- the terminology of 'postsecularism', since the contemporary interweaving of faith, scepticism and unbelief that he traces in $A$ Secular Age does not for him constitute a move beyond the secular. Yet it seems to me there has indeed been something of a 'turn' within the western social imaginary in recent decades away from a more closed or exclusionary immanence, which is helpfully signaled by the language of 'post-secularism'. This isn't to suggest that unadulterated immanence is a thing of the past, but that such secularism no longer seems to be as definingly pervasive or ascendant. For a discussion of these differences and related issues, see Varieties of Secularism in a Secular Age, ed. Michael Warner, Jonathan Vanantwerpen and Craig Calhoun (Cambridge, Massachusetts: Harvard University Press, 2010).

${ }^{27}$ Partial Faiths, 19.

${ }^{28}$ Why I Am Not a Secularist (Minneapolis: University of Minnesota Press, 1999).

29 A World of Becoming, 175.

30 After Finitude: An Essay on the Necessity of Contingency, trans. Ray Brassier (New York: Continuum, 2008), 45-7.

${ }^{31}$ See, for example, 'The Experience of God and the Axiology of the Impossible', Religion after Metaphysics, ed. Mark Wrathall (London: Cambridge University Press, 2003).

32 Derrida, On Cosmopolitanism and Forgiveness (London: Routledge, 2001), 17.

${ }^{33}$ Wby I Am Not a Secularist, 28.

34 Ibid.

35 The Quest: History and Meaning in Religion (Chicago: University of Chicago Press, 1969), 126.

36 Partial Faiths, 3.

${ }^{37}$ Miracles and Pilgrims: Popular Beliefs in Medieval England (London: Dent, 1977), 26.

38 Alexandra Walsham, The Reformation of the Landscape: Religion, Identity \& Memory in Early Modern Britain \& Ireland (Oxford: Oxford University Press, 2011), 9.

${ }^{39}$ Ibid., 151.

40 Ibid., 60; 40.

${ }^{41}$ Ibid., 150. 


\footnotetext{
${ }^{42}$ Ibid., 151-2.

43 Ibid., 174.

${ }^{44}$ R.W. Scribner, 'Ritual and Popular Religion in Catholic Germany at the Time of the Reformation', Journal of Ecclesiastical History, 35:1 (1984), 71.

45 This should be compared to the preceding example ('There moans a strange unearthly sound') and the one that appears a few stanzas earlier in Childe Harold ('There breathes a living fragrance from the shore').

46 Byron: A Poet before His Public (Cambridge: Cambridge University Press, 1982), 71.

47 On Religion: Speeches to its Cultural Despisers, trans. Richard Crouter ([1799] Cambridge: Cambridge University Press, 1988), 31.

48 'The Work and Complement of Appearing', Religious Experience and the End of Metaphysics, ed. Jeffrey Bloechl (Bloomington: Indiana University Press, 2003), 89.

${ }^{49}$ This is how Martin Buber recommends we should read the Bible; Israel and the World: Essays in a Time of Crisis (New York: Schocken Books, 1948), 93.

${ }^{50}$ Emily Dickinson, 'I dwell in Possibility'.

51 Wordsworth's Great Period Poems (Cambridge: Cambridge University Press, 1986), 57.

52 'Criticism and Crisis', in Blindness and Insight (London: Methuen, 1983), 18.

53 The Beauty of Inflections: Literary Investigations in Historical Method and Theory (Oxford: Clarendon Press, 1988), 334.

54 The Romantic Ideology (Chicago: Chicago University Press, 1983), 1.

55 Wilkie, Romantic Poets and Epic Tradition (Madison: University of Wisconsin Press, 1965); Gleckner, Byron and the Ruins of Paradise (Baltimore: Johns Hopkins Press, 1968); McGann, Byron and Romanticism (Cambridge: Cambridge University Press, 2002; LaChance, 'Byron's Bad English', English, 50 (Summer 2001); Tuite, Lord Byron and Scandalous Celebrity (Cambridge: Cambridge University Press, 2015).

56 Nachlass, Nietzsche Werke, ed. Giorgio Colli and Mazzino Montinari (Berlin: de Gruyter, 1973), V, 2, 11.
} 